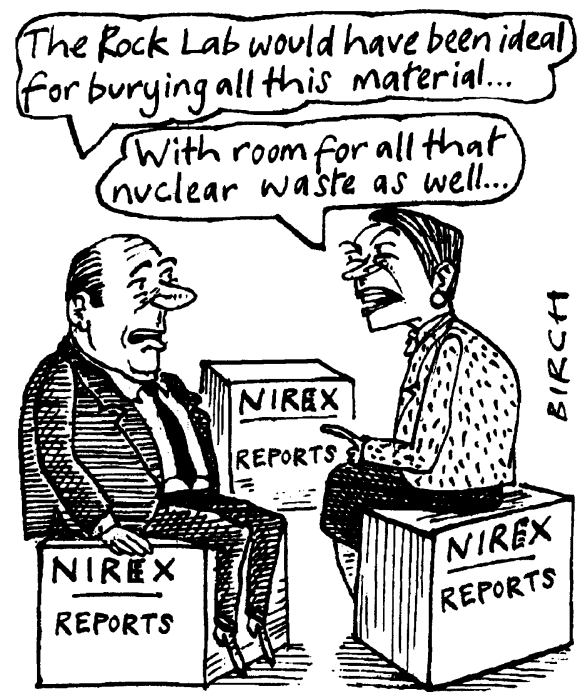

recurring complaint of critics of Nirex for several years. Several external bodies, including the Royal Society, and more recently the government's Radioactive Waste Management Advisory Committee (RWMAC), had called on Nirex to open up its research to independent peer review.

Another criticism is that scientists at Nirex were under pressure to deliver results by unrealistically short deadlines set by senior management. "There is never any time for reflection or analysis," says one former Nirex employee. "We just drill borehole after borehole."(Despite requests, no response had been received from Nirex on these points as Nature went to press).

Rachel Western, senior nuclear officer for FoE, says the public has lost trust in Nirex, and that the government should have taken a tighter regulatory line.

She says it is time for the creation of a new and independent body that meets the original terms of a 1976 Royal Commisson on Environmental Pollution report on radioactive waste management, known as the 'Flowers report', which first called for the creation of a waste disposal agency. "This report made clear that such an agency had to be independent of the nuclear industry."

But others, such as Sir John Knill, former chairman of RWMAC, disagree on the grounds that representation from the nuclear industry is important if the agency is to have influence within the industry. "I do not believe that the body need be totally independent and the Flowers report does not suggest this," he says.

Morris of Nirex says that the company is now "happy to discuss with government and all other interested parties the future direction of government policy and how it can be implemented with public confidence".

Knill says that "an effective balance could be struck between nuclear and non-nuclear interests ensuring that particular expertise was properly represented". But he emphasizes that "the body would have to operate in a transparent manner and be responsive to the need to gain public confidence". EnsanMasood

\title{
Japanese technology fund faces ministry criticism
}

[TOKYO] The Japanese government is to review the activities of the Japan Key Technology Centre (Japan Key-TEC), which funds more than 60 semi-private research institutes, after public criticism of the effectiveness with which the research funds are being used.

A total of $¥ 220$ billion (US $\$ 1.78$ billion) has been spent by the organization since 1985. But the Ministry of Finance is said to be among those concerned that this investment has produced very little return, and that the return is unlikely to increase significantly in the future. Some see the ministry as attempting to raise a question mark over the government's promise to make a massive increase in research spending.

Although the government's budget for the fiscal year 1997 (which began on 1 April) is the tightest for nine years, it will increase spending on science and technology by 11.7 per cent (see Nature 385, 104; 1997). Included is an increase of $¥ 20$ billion for research at Japan Key-TEC.

The Ministry of Trade and Industry (MITI), which oversees Japan Key-TEC with the Ministry of Posts and Telecommunications (MPT), announced last week that it intends to take steps to increase the productivity of the research projects it funds. One strategy will be to increase support for small to medium-sized companies, and to review the activities of research institutes considered to be unproductive.

Japan Key-TEC was set up by MITI and MPT in 1985, following the privatization of Nippon Telegraph and Telephone Corporation, to distribute the income received from government-owned shares in the company (see Nature 359, 577; 1992).

The organization's goal is to promote collaboration between government, industry and academic institutions to enhance research in areas such as biotechnology and telecommunications. Up to $¥ 26$ billion a year has been spent on institutes that are jointly set up by two or more private companies, which contribute 30 per cent to the initial capital investment, with Japan Key-TEC providing the rest.

Some of these institutes have built substantial reputations in basic research. One is the Biomolecular Engineering Research Institute, formerly known as the Protein Engineering Research Institute (PERI), which is supported by 18 companies including Takeda Chemical Industries, Hitachi, Toray Industries and Japan Tobacco.

Each institute receives funding for between five and ten years to complete an agreed research programme. Of 68 institutes set up since 1985, 43 have completed their research programmes and now consist of only a handful of administrative staff retained to handle accounts and analyse research data.

One or two of these institutes, such as PERI, have been re-established under a different name and given a new lease of life. But most of the institutes have fixed terms, to prevent research funding from getting locked into particular fields. The research programmes are expected to file patents, royalties on which are eventually intended to be returned to Japan Key-TEC.

By March last year, 3,187 applications for patents had been made, of which 435 had been accepted and 22 had found successful commercial applications. But, according to MITI, the total return of royalties has been only $¥ 1.3$ billion - a small fraction of the total initial investment of $¥ 220$ billion.

In 1992, the government's Management and Coordination Agency asked the ministries to submit research reports from institutes that had completed their programmes, to recover investment from profitable companies and to close down unprofitable ones.

In reply, both MITI and MPT insisted that returns would come in the long term, and showed little intention of liquidating unprofitable institutes. An official from MITI says that "it is possible to yield profit as long as it is regarded as a long-term project" and that "results from basic research should not be accounted solely in financial terms".

Recent criticisms of Japan Key-TEC projects may be the first sign of a backlash against the government's 'five-year plan', announced last June, to increase spending on science and technology by 50 per cent over the next five years.

The government as a whole has been supportive of increased funding for research and development. But, because of Japan's economic difficulties, the Ministry of Finance may find the forecast expenditure too costly,

According to the reform plan issued last week by MITI, companies that have completed their term and those that are unlikely to yield any profit may be closed down, starting as early as next year. But the director of one of the research institutes thinks this is "highly unlikely" to happen.

There are also plans to increase capital investment in small and medium-sized venture companies - abig change from the previous policy where investment was made only in new research and development institutes. The new plan would bring dividends and profit on the sale of shares after the company's flotation.
AsakoSaegusa 